\title{
Morphological Errors on Japanese Verb Conjugation to Passive Form at Third-Year Students of Japanese Education Study Program of UNP
}

\author{
Meira Anggia Putri
}

Universitas Negeri Padang, Padang, Indonesia, $ه$ (e-mail) meira.anggia@fbs.unp.ac.id

\begin{abstract}
Verbs are a class of words that can stand alone and conjugate. The Japanese verb has various forms of conjugation, and it differs based on the group of the verb. One form of verb conjugation in Japanese is verb change to the passive form. In conjugating verb to passive form, the Japanese learners of UNP frequently make mistakes. Based on linguistic categories, incorrect verb conjugation is categorized as morphological error. Morphological error is a grammatical mistake on a morpheme or word level. According to Dulay (1982), Language errors consist of omission, addition, misformation, and disordering. The purpose of this study is to describe the morphological errors of verb conjugation to the passive form made by Japanese language learners by using surface strategy taxonomy. This research was a qualitative study with a descriptive method. The source of the research data was the answer sheet of the Japanese grammar test of the third-year students of the Japanese education study program of UNP. The research samples were third-year students batch 2017 as many as 30 people from a population of 60 people, who were selected by simple random sampling techniques. The result of this study is the most commonly found mistake in conjugating the verb into passive form is the misformation of the verb.
\end{abstract}

Keywords: Japanese passive form, morphological error, verb conjugation

\section{INTRODUCTION}

In learning Japanese, verb is a class of words learned from the basic level, always appear, and often used in learning. Verb is a type of word that serves as a predicate of a phrase, clause or sentence and contains the meaning of action or deed. In Japanese language, verbs are divided into three groups according to their dictionary form or basic form, which are 1) type I, verbs end in $u, t s u, r u, n u, m u, b u$, $k u, g u$, and $s u ; 2$ ) type II, verbs ending in eru or iru, and 3) type III verb suru and kuru. Hisamitsu and Nitta (1994) stated that Japanese verbs classified into three groups, 1) regular verbs, which are classified into two groups: consonant-stem verbs whose stems end with consonants, and vowel-stem verbs whose stems end with vowels; 2) Sahen-verbs are also classified into two groups: verbal nouns, whose stems can be used as nouns, and the others; 3 ) irregular verb which are kuru and suru.

Japanese verbs can conjugate and stand alone. Sutedi (2014) said that in Japanese the verb or 'doushi' functions as a predicate in a sentence, experiencing a change of form (katsuyou) and can stand alone. The Japanese verbs have different types of conjugation, among them are polite form, conditional form, imperative form, prohibitive form, causative form, passive form, etc. From a variety of conjugation of Japanese verbs, the quite confusing one for Japanese learners is the verb conjugation to passive form.
There are some rules in conjugating Japanese verb to passive form. Sutedi (2014) said that to change Japanese verb to passive form, we have to take verb in negative form as the basis of conjugation, then substitute the ending -nai with -reru for type I verb and rareru for type II. Ishizuka (2010) stated that Japanese passive sentences contain a synthetic passive morpheme -(r)are, which attaches to transitive, ditransitive, and some intransitive predicates. Oshima (2006) also expressed that Japanese passive form with passive morpheme -(r)are. For example, passive verb nom-are-ru, consist of three morphemes, which are 'nom' as content morpheme, morpheme '-are' as the synthetic passive morpheme, and ' $r u$ ' as the function morpheme.

Various verb conjugation and the rules of verb conjugation into the passive form mentioned before, often make the Japanese language learners confused and make many errors in modifying verbs to the passive form. Error in Japanese is called goyou. The meaning of goyou (language error) according to Kawarazaki (1998:4) is when Japanese native speakers briefly hear a second language learner speak or read what he/she writes then feel the confusion about it, then it can be said an error. Ellis (1994) explained that error analysis is a working procedure, commonly used by researchers and language teachers, including sample collection, error identification found in samples, error explanations, classification of error based on the cause, as well as evaluation of the seriousness of the 
error. Error in verb conjugation belongs to the morphological error. According to Nurhadi (1990), the morphological error is an error at the level of change of a morpheme in the construction of the word.

The language error can be analyzed based on surface strategy taxonomy according to Dulay et al. Dulay (1982) wrote that learners might omit necessary items, add unnecessary items, misform the items, or disorder the items. Ellis (1994) also added that the omission indicates the omission of a certain linguistic item that must not appear in a well-formed utterance, addition indicates the addition of a certain linguistic item that must not be appeared in wellformed utterance, misformation indicates the use of an incorrect form of a certain linguistic in the target language utterance, and disordering indicates the incorrect arrangement of a certain linguistic in the target language utterance.

From observations conducted during teaching Japanese at the Japanese language Education Department of UNP, Japanese language learners often make mistakes in conjugating verb to the Japanese passive verbs. For these errors to be minimized, error analysis related to Japanese passive verb conjugation needs to be done. From this, the purpose of this study is to find out the morphological errors of Japanese passive verbs conjugation made by third-year students of the UNP Japanese language education, by using surface strategy theory.

\section{METHOD}

This study uses a qualitative approach with a descriptive method. Yusuf (2017) stated that qualitative research seeks the meaning, understanding, and clarifying a phenomenon, incident, and human life by being directly/indirectly involved. Then the descriptive research focuses on actual problems as they are at the time of the study (Noor, 2011). The descriptive method used to describe the forms of morphological errors in modifying verbs to the Japanese passive verb form. The source of the research data is the answer sheet of the Japanese grammar test of the third-year students of the Japanese education program study UNP. The research samples were third-year students in batch 2017 as many as 30 people from a population of 60 people, who were selected by using simple random sampling techniques.

\section{RESULTS AND DISCUSSION}

Based on research that had been conducted, known that there are 69 errors in the conjugation of verbs made by students, consist of deletion, addition, and misformation. Frequency and percentage of the morphological errors is shown in the following table.

Table 1. Frequency and percentage of morphological errors

\begin{tabular}{|l|l|l|l|}
\hline No & Tipe Kesalahan & Frequency & Percentage \\
\hline 1 & Omission & 5 & $7.25 \%$ \\
\hline 2 & Addition & 3 & $4.35 \%$ \\
\hline 3 & Misformation & 61 & $88.4 \%$ \\
\hline 4 & Disordering & 0 & $0 \%$ \\
\hline
\end{tabular}

\begin{tabular}{|l|l|l|l|}
\hline & Total & 69 & $100 \%$ \\
\hline
\end{tabular}

The table above shows that there are 69 morphological errors in verbs conjugation to passive form. Omission as much as $7.25 \%$ with the amount of 5 errors, addition as much as $4.35 \%$ with the amount of 3 errors, misformation as much as $86 \%$ with the amount of 59 errors. The disorder type of error was not found.

\section{A. Omission}

In conjugating Japanese verb into passive form made by Japanese language learners of UNP, found that there are 5 errors classified to omission with a percentage of $7.25 \%$ of the total error. Ellis (1994) Omission indicates the omission of a certain linguistic item that must not appear in a wellformed utterance. Morphological errors with the type of omission is shown in the following table.

Table 2. Morphological error "omission"

\begin{tabular}{|c|l|l|l|c|}
\hline $\begin{array}{l}\text { Data } \\
\text { Number }\end{array}$ & $\begin{array}{l}\text { Verb } \\
\text { conjugation } \\
\text { error }\end{array}$ & $\begin{array}{l}\text { Passive } \\
\text { form of } \\
\text { verb }\end{array}$ & $\begin{array}{c}\text { Basic } \\
\text { form of } \\
\text { verb }\end{array}$ & Amount \\
\hline 7 & Kororemashita & $\begin{array}{l}\text { Korosarema } \\
\text { shita }\end{array}$ & Korosu & 1 \\
\hline 22 & Nusuremasu & $\begin{array}{l}\text { nusumarem } \\
\text { asu }\end{array}$ & Nusumu & 1 \\
\hline 23 & Kowareru & kowasareru & Kowasu & 1 \\
\hline 24 & Sutereru & suterareru & Suteru & 2 \\
\hline & & Total & & 5 \\
\hline
\end{tabular}

The table above shows the student's errors in conjugating the verb by omitting phonemes from morpheme on the verb. Here are some explanations of passive verb conjugation errors in the type of omission.

Data (7) kororemashita

Basic verb: korosu

Meaning: to kill

Passive verb in 'masu' form: koros-are-mashita

Verb conjugation error: koro-re-mashita

Omission: Phoneme " $s$ " of content morpheme "koros" and phoneme " $a$ " of passive morpheme "-are"

At data (7) shows that In changing the basic form of type I verb "korosu" into passive form, the phoneme s removed from the content morpheme "koros" and phoneme " $a$ " from passive morpheme "-are". The omission happened on both morphemes of the passive verb "korosareru", makes the word has no meaning.

Data (22) nusuremasu

Basic verb: nusumu

Meaning : to steal

Passive verb in 'masu' form: nusum-are-masu

Verb conjugation error: nusu-re-masu

Omission: phoneme " $m$ " of content morpheme "nusum" and phoneme ' $a$ ' of passive morpheme "-are"

At data (22) shows that In changing the basic form of type I verb "nusumu" into passive form, the phoneme 
' $m$ ' removed from the content morpheme "nusum" and phoneme " $a$ " from passive morpheme "-are". The omission occurred on those both morphemes of the passive verb "nusumareru", makes the word has no meaning.

Data (23) kowareru

Basic verb: kowasu

Meaning : to break

Passive verb: kowas-are-ru

Verb conjugation error: kowa-re-ru

Omission: phoneme "s" of content morpheme "kowas" and phoneme " $a$ " of passive morpheme "-are"

At data (23) shows that In changing the basic form of type I verb "kowasu" into passive form, the phoneme "s" removed from the content morpheme "kowas" and phoneme " $a$ " from passive morpheme 'are'. The omission happened on both morphemes of the passive verb "kowasareru", makes the word change from passive to intransitive verb "kowareru".

Data (24) sutereru

Basic verb: suteru

Meaning : to throw away

Passive verb: sute-rare-ru

Verb conjugation error: sute-re-ru

Omission: syllable " $r a$ " from passive morpheme "-rare"

In data (24) shows that in conjugating verb "sutereru", learners removed the syllable ' $r a$ ' from the passive morpheme "rare". The omission of both phonemes from passive morpheme "-rare" change the verb form into "potential" form. From verb passive form "suterareru" means "thrown away" became potential form "sutereru" means "able to throw away"

\section{B. Addition}

In the Japanese verb conjugation to passive form made by Japanese language learners of UNP, there are 3 errors classified to 'addition' with a percentage of $4.35 \%$ of total errors. Ellis (1994) described that 'Addition' indicates the addition of a certain linguistic item that must not be appeared in a well-formed utterance. Morphological errors 'addition' type is shown in the following table.

Table 3. Morphological error "addition"

\begin{tabular}{|l|l|l|c|c|}
\hline $\begin{array}{l}\text { Data } \\
\text { Number }\end{array}$ & $\begin{array}{l}\text { Verb } \\
\text { conju- } \\
\text { gation } \\
\text { error }\end{array}$ & $\begin{array}{l}\text { Passive form } \\
\text { of verb }\end{array}$ & $\begin{array}{c}\text { Basic } \\
\text { form } \\
\text { of } \\
\text { verb }\end{array}$ & Amount \\
\hline 8 & $\begin{array}{l}\text { fumasar } \\
\text { emashita }\end{array}$ & fumaremashita & Fumu & 1 \\
\hline 28 & $\begin{array}{l}\text { fumarar } \\
\text { eru }\end{array}$ & fumareru & Fumu & 1 \\
\hline 29 & $\begin{array}{l}\text { kawarar } \\
\text { eru }\end{array}$ & kawareru & Kau & 1 \\
\hline & & Total & & 3 \\
\hline
\end{tabular}

The table above shows the student's error in conjugating the verb by adding phonemes to morpheme on the verb. Here are some explanations of passive verb conjugation errors in the type of addition.

Data (8) fumasaremashita

Basic verb: fumu

Meaning : to step on

Passive verb in past 'masu' form: fum-are-mashita

Verb conjugation error: Fuma-sare-mashita

Addition : phoneme " $a$ " to content morpheme "fum" and phoneme "s" to passive morpheme "-are"

At data (8) shows that In changing the basic form of type I verb "fumu" into passive form, the phoneme " $a$ " was added to the content morpheme "fum" and phoneme " $s$ " to passive morpheme "-are". Then, at data (26) shows that in changing verb "korosu" to passive form, the phoneme " $u$ " was added to the content morpheme "koros", and the phoneme " $s$ " was added to the passive morpheme "are". The wrong construction that happened to the word makes the word has no meaning in Japanese lexicons.

\section{Data (28) fumarareru}

Basic verb: fumu

Meaning : to step on

Passive verb: fum-are-ru

Verb conjugation error: fuma-rare-ru

Addition : phoneme " $a$ " to content morpheme "fum", phoneme " $\mathrm{r}$ " to passive morpheme "-are"

At data (28) shows that In changing the basic verb into passive form, the phoneme 'a' was added to the content morpheme and phoneme " $r$ " to passive morpheme "-are". This is also occurred at data (29) (see table 3). The wrong construction that happened to these words makes the word has no meaning in Japanese lexicons.

\section{Misformation}

In Japanese verb conjugation to the passive form made by Japanese language learners of UNP, there are 61 errors which belong to misformation with a percentage of $88.4 \%$ of total errors. This is the largest number of errors found in this study. Ellis (1994) stated that misformation indicates the use of an incorrect form of a certain linguistic in the target language utterance. Morphological errors "misformation" type is shown in the following table. 
Table 4. Morphological error "misformation"

\begin{tabular}{|c|c|c|c|c|}
\hline $\begin{array}{l}\text { Data } \\
\text { Number }\end{array}$ & Verb conjugation error & Passive form of verb & Basic form of verb & Amount \\
\hline 1 & Awaremasu & Ai saremasu & ai suru & 5 \\
\hline 2 & Sutarareru & Suterareru & Suteru & 3 \\
\hline 3 & Nusuraremasu & Nusumaremasu & nusumu & 1 \\
\hline 4 & Shikareru & shikarareru & Shikaru & 7 \\
\hline 5 & Yabureru & yaburareru & Yaburu & 7 \\
\hline 6 & Kausareru & Kawaremasu & Kau & 1 \\
\hline 9 & Tsukararemasu & Tsukuraremasu & Tsukuru & 2 \\
\hline 10 & Nagureru & nagurareru & Naguru & 7 \\
\hline 11 & Tsukureru & tsukurareru & Tsukuru & 4 \\
\hline 12 & Nusumureru & Nusumareru & Nusumu & 1 \\
\hline 13 & Fumireru & Fumareru & Fumu & 1 \\
\hline 14 & Korosureru & Korosareru & Korosu & 1 \\
\hline 15 & Toreru & torareru & Toru & 3 \\
\hline 16 & Fureru & furareru & Furu & 2 \\
\hline 18 & Sureru & Sareru & Suru & 1 \\
\hline 19 & Nusumeru & Nusumareru & Nusumu & 1 \\
\hline 20 & Fumeru & Fumareru & Fumu & 1 \\
\hline 21 & Suwareru & suwarareru & Suwaru & 3 \\
\hline 25 & Fumuraremasu & Fumareru & Fити & 1 \\
\hline 26 & korosusaremasu & korosaremasu & Korosu & 1 \\
\hline 27 & Okoreta & okorareta & Okoru & 1 \\
\hline 30 & nagururareru & nagurareru & Naguru & 1 \\
\hline 31 & Torusareru & Torareru & Toru & 1 \\
\hline 32 & korosaseraremashita & korosaremashita & Korosu & 1 \\
\hline 33 & naosaseraremashita & naosaremashita & Naosu & 1 \\
\hline 34 & aureru & Aisareru & aisuru & 1 \\
\hline 35 & Aisasemasu & Aisareru & Ai suru & 1 \\
\hline \multirow[t]{2}{*}{36} & Shuuri sasemasu & shuuri saremasu & Shuuri suru & 1 \\
\hline & Total & 61 & & \\
\hline
\end{tabular}

The table above shows the student's errors in conjugating the verb in misformation Here are some explanations of passive verb conjugation errors in the type of misformation.

\section{Conjugating Noun}

Data (1) awaremasu

Basic verb: ai suru

Meaning : to love

Passive verb in 'masu' form: ai. s-are-masu

Verb conjugation error: aw-are-masu

misformation: changing noun " $a i$ " with passive rules

Data (1) shows the learners didn't know that "ai" is noun. Noun cannot be conjugated. To convey verb "love", "ai" as noun has to be followed with auxilliary -suru. So to say word 'be loved', word "ai suru" has to be changed to the passive form, by changing the aux. -suru to its passive form. However, the learners didn't know about that, so they wrote "awaremasu" instead, because they thought word "ai" is a verb. They changed the noun "ai" with passive rule by changing phoneme " $i$ " to syllable " $w a$ " then connected it with passive morpheme "-are".

Data (34) aureru

Basic verb: ai suru

Meaning : to love

Passive verb in 'masu' form: ai s-are-masu

Verb conjugation error: au-reru

misformation: changing noun morpheme " $a i$ " to " $a u$ " then attach it to passive morpheme "reru"

Data (34) shows the learner didn't know that "ai" is a noun. To convey verb "to love', "ai" as noun has to be followed with auxilliary "suru". So to say word 'be loved' word "ai suru" has to be changed to passive form. To conjugate passive verb of verbal noun "ai suru" is by changing the auxiliary -suru to passive form "sareru". However, the learners didn't understand about that, so they wrote "aureru" instead, because they thought word " $a u$ " is a verb form of " $a i$ ". They changed the noun 'ai' to ' $a u$ ' assuming ' $a u$ ' is verb form of " $a i$ ", then attached it to "reru". Why did they attach it with reru, because they thought that to change a verb to passive form, it has to be followed by -reru.

Data (35) aisasemasu 
Basic verb: ai suru

Meaning : to love

Passive verb in 'masu' form: ai s-are-masu

Verb conjugation error: ai s-ase-masu

misformation: using causative morpheme instead of passive morpheme

Data (35) shows that to change verbal noun to passive form, the aux. suru has to be attached to passive morpheme. But in this case what was attached to aux. suru is causative-passive morpheme, so the word conveyed different meaning. Instead of "ai saremasu" which means 'be loved', the word became "ai sasemasu" which means 'made/let someone to love'. This kind of error also occurred at data (36).

\section{Substituting phoneme of content morpheme}

Data (2) sutarareru

Basic verb: suteru

Meaning : to throw away

Passive verb: sute-rare-ru

Verb conjugation error: suta-rare-ru

misformation: substituting content morpheme final phoneme to ' $a$ ' sound

Data (3) nusuraremasu

Basic verb: nusumu

Meaning : to steal

Passive verb in 'masu' form: nusum-are-masu

Verb conjugation error: nusur-are-masu

misformation: substituting phoneme ' $m$ ' at the end of content morpheme/verb stem with phoneme ' $r$ '.

Data (2) shows that in changing verb "suteru" to passive form, the phoneme " $e$ " at the end of the content morpheme was changed with phoneme " $a$ ". So the word became "sutareru" which doesn't have any meaning in Japanese lexicons. Then, in Data (3) known that in changing verb "nusumu" to passive form, phoneme " $m$ " at the end of content morpheme changed with phoneme " $r$ ", so the word become "nusuraremasu" which also doesn't have any meaning in Japanese lexicons.

\section{Basic verb connected with unknown morpheme -} sare

Data (6) kausareru

Basic verb: kau

Meaning : to buy

Passive verb : kaw-are-ru

Verb conjugation error: kau-sare-ru

misformation: the basic verb attached with '-sareru'

Data (6) shows that in conjugating the basic verb into passive form, the verbs weren't changed with the right passive rules. They merely attach the basic verb with sareru, in result these words don't have any meaning in Japanese lexicons. This kind of error also occurred at data (26) and (31).

\section{Substituting phoneme of passive morpheme}

Data (12) nusumureru

Basic verb: nusumu

Meaning : to steal

Passive verb: nusum-are-ru

Verb conjugation error: nusum-ure-ru

misformation: Substituting phoneme " $a$ " of passive morpheme with " $u$ ".

Data (12) shows that in conjugating verb to passive form, the first phoneme of passive morpheme '-are' substituted with phoneme " $u$ ". In result, words in wrong form were made, like "nusumureru". This kind of error also occurred at data (14) and (18).

Data (13) fumireru

Basic verb: fumu

Meaning: to step on

Passive verb: fum-are-ru

Verb conjugation error: fum-ire-ru

Misformation: Substituting phoneme ' $a$ ' of passive morpheme with ' $i$ '.

At Data (13) known that in conjugating verb "fumu" to passive form, first phoneme in passive morpheme was changed with phoneme ' $i$ ', so the word constructed became 'fumireru' which doesn't exist and has no meaning in Japanese lexicons.

\section{Using potential morpheme instead of passive} morpheme

Data (4) shikareru

Basic verb: shikaru

Meaning: to scold

Passive verb: shikar-are-ru

Verb conjugation error: shikar-e-ru

misformation: using potential morpheme ' $e$ ' instead of passive morpheme '-are'

Data (4) shows that in conjugating verb type I end in " $r u$ " to passive form, instead of passive morpheme, learners attached potential morpheme to the content morpheme, so the word conveyed different meaning, "shikarareru" which means "scolded' became 'able to scold'. The same case happened to other data with verb " $r u$ " end, which are data $5,10,11,15,16,21,27$. This kind of error is the largest number found, as many as 34 errors in total.

Data (19) nusumeru

Basic verb: nusumu

Meaning: to steal

Passive verb: nusum-are-ru

Verb conjugation error: nusum-e-ru

misformation: using potential morpheme " $e$ " instead of passive morpheme "-are"

Data (19) show that in conjugating verb type I end in " $m u$ " to passive form, instead of passive morpheme, learners attached potential morpheme to the content morpheme, so the word conveyed different meaning. Like in data (19), not “nusumareru” which means 'stolen', the 
word became "nusumeru” which means 'able to steal'. This kind of error also occurred at data (20).

\author{
6. Basic verb connected with passive morpheme "rare" \\ Data (25) fumuraremasu \\ Basic verb: fumu \\ Meaning: to step on \\ Passive verb: fum-are-ru \\ Verb conjugation error: fumu-rare-masu \\ misformation: basic verb attached with passive morpheme \\ 'rare'
}

Data (25) shows that in conjugating the basic verb to passive form, the verb wasn't changed with the right passive rules. Firstly, the basic verb without conjugation attached to passive morpheme "-rare". Secondly, passive morpheme "-rare" should be attached to type II verb only, in this case, verb "fumu" is type I verb, so this verb shouldn't attach to passive morpheme "-rare" but "are". As a result, this word doesn't have any meaning in Japanese lexicons. This kind of error also occurred at data (30).

\section{Using causative-passive morpheme instead of passive morpheme}

Data (32) korosaseraremashita

Basic verb: korosu

Meaning: to kill

Passive verb in 'masu' form: koros-are-ru

Verb conjugation error: koros-aserare-mashita

misformation: using causative-passive morpheme instead of passive morpheme

Data (32) shows that in conjugating verb type I end in " $s u$ " to passive form, instead of of passive morpheme, causative-passive morpheme was attached to the content morpheme, so the word conveyed different meaning. Like in data (32), the passive verb "korosaremashita" which means 'killed' became "korosaseraremashita" which means 'was made to kill'. This kind of error also occurred at data (33)

\section{CONCLUSIONS}

Based on the finding and discussion of this study, known that the errors that the Japanese education program study of UNP made in conjugating Japanese verb to passive form are omission, addition, and misformation, but disordering type of error was not found. There are 5 errors classified to omission with percentage of $7.25 \%, 3$ amount of errors belong to addition with percentage of $4.35 \%$. The largest number of errors found belongs to "misformation" with a total of 61 errors and a percentage of $88.4 \%$. Among the "misformation" errors, can be grasped that the most error the learners made (36 amount of errors) was using potential morpheme $-e$ instead of passive morpheme -are. From the error of using potential morpheme instead of passive morpheme known that many learners confused in conjugating type I verb ending in $r u$ to passive form(there are 34 errors found in this kind of error). Because they overgeneralized that verb type I should end with -reru, so when the learner conjugated verb type I ending in syllable $r u$, they directly change that syllable ru into reru, affecting the construction of word changed to potential form.

\section{REFERENCES}

[1] Dulay, H., Burt, M., \& Krashen, S. (1982). Language two. Oxford: Oxford University Press.

[2] Ellis, R. (1994). The study of second language acquisition. Oxford: Oxford University Press.

[3] Hisamitsu, T., \& Nitta, Y. (1994). An efficient treatment of Japanese verb inflection for morphological analysis. In Proceedings of the 15th conference on Computational linguistics-Volume 1 (pp. 194-200). Association for Computational Linguistics.

[4] Ishizuka, T. (2010). Toward a unified analysis of passives in Japanese: A cartographic minimalist approach. University of California, Los Angeles.

[5] Kawarazaki, Mikio. (1998). Nihongo Kana Nyumon. Tokyo: The Japan Foundation.

[6] Noor, Juliansyah. (2011). Metodologi Penelitian: Skripsi, Tesis, Disertasi dan Karya Ilmiah. Jakarta: Kencana.

[7] Nurhadi, Roekhan. (1990). Dimensi-dimensi dalam Belajar Bahasa Kedua. Bandung: Sinar Baru.

[8] Oshima, D. Y. (2006). Adversity and Korean/Japanese passives: constructional analogy. Journal of East Asian Linguistics, 15(2), 137-166.

[9] Sutedi, Dedi. (2014). Penelitian Pendidikan Bahasa Jepang. Bandung: Humaniora.

[10] Yusuf, A. Muri. (2017). Metode Penelitian Kuantitatif, Kualitatif dan Penelitian Gabungan. Jaka 